\title{
Relationships between the intra-ring wood density assessed by X-ray densitometry and optical anatomical measurements in conifers. Consequences for the cell wall apparent density determination
}

\author{
Valérie DECOUX ${ }^{\mathrm{a}}$, Éliane VARCIN ${ }^{\mathrm{b}}$, Jean-Michel LEBAN ${ }^{\mathrm{b} *}$ \\ a Université Libre de Bruxelles, 50 av. FD Roosevelt, SAAS-CP165/55, 1050 Brussels, Belgium \\ ${ }^{\mathrm{b}}$ INRA Champenoux, Équipe Qualité des Bois, France
}

(Received 25 September 2002; accepted 21 May 2003)

\begin{abstract}
The objective of this work is to compare anatomical measurements to wood density variations within annual rings of three major softwood species, Norway spruce, Scots Pine and Silver Fir. The six selected annual rings were sampled within a database of thousand microdensitometric profiles measured on wood samples collected in Finland and France. Each of the six studied annual rings represents one average profile of wood density for a given age class and age ring width. The dimensions of the tracheids are performed in the radial-tangential plane by using two different planimetric methods. The wood density profile within each ring is calculated simply by the mean of the tracheid dimensions and by using a constant value for the cell wall density. We have verified that the knowledge of the (i) tracheid geometry and (ii) the usually admitted value of the cell wall density allows us to calculate intra ring wood density profiles which are similar to the X-rays wood density profiles in terms of variations but very different in average. Thus it appears necessary to calibrate by using an apparent cell wall density varying inside the rings and being far weaker than the effective cell wall density of $1460 \mathrm{~kg} / \mathrm{m}^{3}$ as it is usually admitted in the literature.
\end{abstract}

wood density / wood anatomy / Picea abies / Pinus silvestris / Abies alba

Résumé - Variations intra-cerne de densité du bois et mesures optiques des caractéristiques anatomiques de résineux. Conséquences pour la détermination de la densité apparente de paroi. L'objectif de ce travail est comparer des mesures anatomiques à des mesures de variations de densité du bois à l'intérieur de cernes annuels pour trois essences résineuses importantes, l'épicéa commun, le sapin pectiné et le pin sylvestre. Les cernes sélectionnés sont choisis dans un échantillon de plusieurs milliers de cernes prélevés dans des arbres en France et en Finlande. Chaque cerne étudié représente pour une essence le profil moyen de densité d'une classe d'âge compté depuis la moelle et d'une classe de largeur de cerne. Les caractéristiques géométriques des trachéides sont mesurées par deux méthodes planimétriques différentes dans le plan radial-tangentiel. Le profil de densité du bois est calculé simplement à partir des dimensions des trachéides et de la densité de la matière ligneuse. Pour que le profil calculé de densité du bois corresponde au profil obtenu par microdensitométrie nous avons montré qu'il est nécessaire faire varier le facteur de calibration, appelé densité apparente de la paroi cellulaire, à l'intérieur des cernes avec des valeurs bien plus faibles que $1460 \mathrm{~kg} / \mathrm{m}^{3}$, la valeur habituellement utilisée dans la littérature.

densité du bois / anatomie / Picea abies / Pinus silvestris / Abies alba

\section{INTRODUCTION}

Basically all physical properties of wood are determined by factors inherent in its structural organisation. These can be summarised as: (i) the amount or proportion of cell wall substance present in a given piece of wood and (ii) the spatial arrangement of the wall substance. Wood density is a measurement of the quantity of material contained in a certain volume but it gives no information on its spatial distribution.

As wood density provides a good but limited explanation of the wood properties, we believe that consideration of the ana- tomical characteristics could allow a better understanding of this material behaviour. Because the ring anatomy represents the expression of the tree genotype at a given height and cambial age and under the annual growth conditions (precipitation, temperature, soil...), it appears to be the link between the tree physiology and the wood quality.

At present, the main approach of the anatomy - wood density relationship consists of the estimation of a calibration factor called the cell wall apparent density [19, 29, 33, 41, 43, 47] based on the measurements of (i) the density of a wood sample, a wood block for gravimetry or a $2 \mathrm{~mm}$ thick section for X-ray

\footnotetext{
* Corresponding author: leban@ @ancy.inra.fr
} 
Table I. Breakdown of the studied rings.

\begin{tabular}{lcccc}
\hline Species & Age of the ring (years) & Mean bulk density $\left(\mathrm{kg} / \mathrm{m}^{3}\right)$ & Ring width $(\mu \mathrm{m})$ & Year \\
\hline Finland spruce (FinS) & 36 & 471 & 2680 & 1938 \\
France spruce (FraS) & 35 & 482 & 2850 & 1956 \\
France fir (FraF) & 49 & 509 & 2760 & 1985 \\
France pine (FraP) & 35 & 527 & 2690 & 1977 \\
North Finland pine (NFinP) & 52 & 526 & 1280 & 1916 \\
South Finland pine (SFinP) & 54 & 597 & 2070 & 1954 \\
\hline
\end{tabular}

and (ii) the cell wall proportion on its area or on a section withdrawn from it. The apparent density of the cell wall is then obtained from the wood density divided by the cell wall proportion by making the following assumptions.

The cell wall proportion is constant within each sample thickness, in other words the longitudinal tracheids and their walls are uniformly wide throughout their length. This appears reasonable as only the tracheid pits are sharp and as the tracheids are at least a few mm long.

The tracheids occupy the whole wood volume. Indeed in coniferous wood the tracheids represent more than $93 \%$ of the total number of cells [3].

This wood density/cell wall proportion ratio should be a measure of the wood matter density (cell walls, middle lamella, walls of ray cells and canals), which is considered as cell wall density [29, 32, 43], and is sometimes called apparent density of the solid substance [47], specific gravity of the cell wall [30, $33]$ or packing density $[18,41]$.

In the literature the relationships between wood density and tracheid dimensions are difficult to compare since different variables were measured, with different techniques and on different species.

The relative importance of different tracheid dimensions on wood density can be assessed by multiple regression analysis using the criterion of adjusted $R^{2}[14,21]$ but without taking possible serial correlation into account neither the non stationary character of the measurements all along a ring and with only a limited number of available anatomical characteristics.

In a different way, Wimmer [46] has proposed a numeric wood density model based on a rectangular and uniform tracheid shape in cross section whose differentiation allows an evaluation of how individual anatomical parameters mathematically change wood density.

The multiple linear regressions approach [14] shows that (i) the earlywood lumen diameters (radial and tangential) and (ii) the latewood proportion have both the strongest relationships with wood density. The tracheid dimensions are less good predictors for wood density at age 3-4 than at age 21-26.

For Lindström [21], wood density is found dependent on latewood percentage and the inverted value of the earlywood radial tracheid diameter $\left(R^{2}=0.80\right)$. Wimmer [46] confirms the latewood percentage being a good predictor for wood density.

This study intends to compare the evolution of the intra ring density and of anatomical characteristics measured on the transverse plane all along the ring in order to obtain an anato- mical interpretation of the wood density microvariations measured by X-ray. At the same time, it will be possible to compare two optical methods of measurement of the anatomical characteristics: manual (planimetry) and automated (image analysis).

The manual method implies (i) to count the total number of tracheids and (ii) to measure the cell wall thickness. Based on these figures, with the support of one simple geometric model and by the mean of the expected value for the cell wall density, it is possible to calculate the wood density variations. Such approach permits to rely simply the wood anatomy to the wood density. Two simple geometric models for the tracheids are tested in order to determine their sensitivity to the wood density calculation.

As image analysis is the most used tool for wood anatomy, we have compared the planimetric method to the image analysis method. This method involves several processes such as thresholding that can affect the cell wall proportion measurement.

Our objective is to examine for three softwood species, how the intra ring wood density can be exactly predicted by the knowledge of (i) the tracheid geometry, actual or simulated, and of (ii) the packing density of the cell wall.

\section{MATERIALS AND METHODS}

\subsection{Samples selection}

From a previous work done by the Wood Quality Team from INRA-Champenoux Centre, the microdensitometric data and the mounted microtomic sections ( $12 \mu \mathrm{m}$ thick, stained with safranin) of three conifers species (Picea abies, Pinus silvestris and Abies alba) of different origins (North East France, North and South Finland) were available. The microdensitometric data were classified in age classes of 30 years and ring widths of $1 \mathrm{~mm}$. Only the classes containing data for more than 50 rings and at least 5 trees were kept. For each of these classes, a mean microdensitometric profile was calculated and within our data base we have selected the ring, whose actual densitometric profile was the closest to the calculated mean profile.

Table I presents a breakdown of the studied samples.

\subsection{Microdensity determinations}

The densities of the six selected rings were obtained from X-ray densitometry (Joyce Loebl) of $2 \mathrm{~mm}$ thick sections, air dried at $12 \%$ moisture content $[26,27]$. This method allows to measure density microvariations $[20,22]$ as the radial step of measurement may be as 
Table II. X-ray densitometric values $\left(\mathrm{kg} / \mathrm{m}^{3}\right)$ for each part of the six rings.

\begin{tabular}{lccccccccccccccccccccc}
\hline & 1 & 2 & 3 & 4 & 5 & 6 & 7 & 8 & 9 & 10 & 11 & 12 & 13 & 14 & 15 & 16 & 17 & 18 & 19 & 20 \\
\hline FinS & 363 & 285 & 299 & 307 & 319 & 317 & 316 & 328 & 340 & 361 & 397 & 433 & 455 & 498 & 554 & 642 & 713 & 765 & 864 & 867 \\
FraS & 351 & 286 & 289 & 288 & 300 & 306 & 318 & 338 & 364 & 396 & 420 & 442 & 456 & 479 & 516 & 592 & 685 & 827 & 962 & 1027 \\
FraF & 330 & 287 & 286 & 303 & 314 & 327 & 337 & 351 & 382 & 420 & 453 & 505 & 552 & 620 & 700 & 716 & 783 & 814 & 842 & 861 \\
FraP & 417 & 325 & 309 & 319 & 324 & 324 & 312 & 307 & 317 & 353 & 426 & 509 & 583 & 569 & 709 & 824 & 882 & 925 & 939 & 862 \\
NFinP & 433 & 371 & 352 & 361 & 362 & 354 & 366 & 376 & 375 & 378 & 396 & 425 & 479 & 530 & 628 & 746 & 826 & 921 & 959 & 875 \\
SFinP & 508 & 374 & 355 & 346 & 348 & 360 & 383 & 398 & 406 & 427 & 453 & 530 & 706 & 817 & 845 & 859 & 975 & 997 & 998 & 862 \\
\hline
\end{tabular}

small as $25 \mu \mathrm{m}[23,24]$. The investigated width is $1000 \mu \mathrm{m}$ in the tangential direction.

The microdensitometric data of the six rings are presented in Table II. The rings were divided in 20 equal parts in the radial direction, a mean being calculated for each one.

\subsection{Planimetric method}

The six sections were photographed with an enlargement of 45 . A window was disposed on each ring of a radial size equal to the ring width. The tangential width of the window depended on the width of the section and straightness of the ring limits. The selected widths were $3000 \mu \mathrm{m}$ for Finland spruce, France spruce and France fir; $1500 \mu \mathrm{m}$ for France pine and South Finland pine and $1000 \mu \mathrm{m}$ for North Finland pine. When rays or canals were present, the measured area was limited to the area occupied by tracheids only.

Each ring was then divided in 20 equal parts in the radial direction.

Anatomical measurements were made by human eye with a micrometric scale integrated into a magnifying glass. The tracheids only were taken into account.

For the six rings we obtained the number of cells per length unit by counting the total number of tracheids in both radial and tangential directions. The cell wall thickness was measured for only 50 tracheids randomly selected in each of the 20 parts of each ring, for both radial and tangential directions. The total number of tracheids counted in the radial direction vary among each divided part of the rings by a factor 2 . For instance this number vary from 64 up to 117 tracheids for a narrow ring (North Finland pine) and from 131 up to 240 for a wider ring (South Finland pine).

From these measurements (i) the mean tracheid sizes in the radial and tangential directions and (ii) the mean cell wall thickness were obtained for each ring.

Two simple geometric models were then used and tested in order to display these results in terms of intra ring wood density variation. The tracheids are assumed to be rectangle or hexagonal shaped in the transverse plane (Fig. 1). The second model was considered because the rectangular model does not fit well the visual pattern of the observed softwoods tracheids.

\subsubsection{Rectangular model}

$\mathrm{R}=$ mean radial size of the cell $=($ ring width $/ 20) /$ number of cells on a radial length of (ring width/20); $\mathrm{T}=$ mean tangential size of the cell $=$ width of the window of measurement $/$ number of cells on the tangential width of the window of measurement; $\mathrm{x}=$ mean cell wall width, with: $\mathrm{S}=$ mean cell area; $\mathrm{s}^{\prime}=$ mean lumen area; $\mathrm{s}=$ mean cell wall area $=\mathrm{S}-\mathrm{s}$.

$$
\begin{aligned}
& S=R \cdot T, \\
& s^{\prime}=(R-2 x) \cdot(T-2 x) .
\end{aligned}
$$
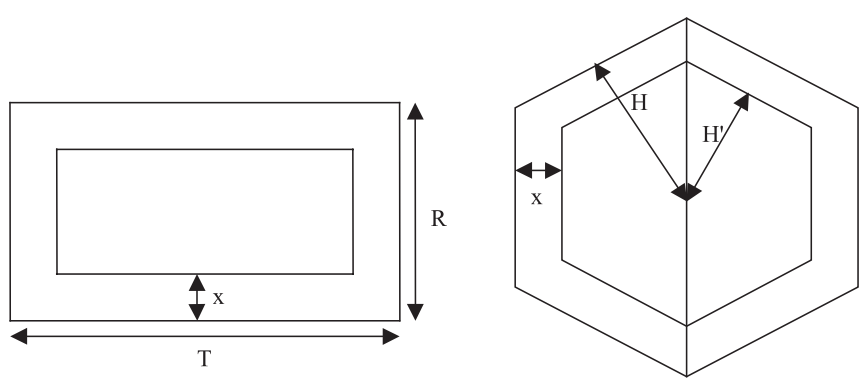

Figure 1. Rectangular (left) and hexagonal (right) cell and lumen models.

Let $X=2 \cdot x=$ width of the double cell wall:

$\mathrm{s}=\mathrm{R} \cdot \mathrm{T}-[(\mathrm{R}-\mathrm{X}) \cdot(\mathrm{T}-\mathrm{X})]$,

$\mathrm{s}=\mathrm{X} \cdot(\mathrm{T}+\mathrm{R})-\mathrm{X}^{2}$,

$\mathrm{S} / \mathrm{S}=$ cell wall proportion.

If $\mathrm{drx}=$ the wood density measured by $\mathrm{x}$ ray: apparent density of the cell wall $=\mathrm{drx} /$ cell wall proportion $=\mathrm{drx} \cdot \mathrm{S} / \mathrm{s}$

$$
\begin{aligned}
& =\mathrm{drx} \cdot \mathrm{R} \cdot \mathrm{T} /\left[\mathrm{X} \cdot(\mathrm{T}+\mathrm{R})-\mathrm{X}^{2}\right] \\
& =\mathrm{drX} \cdot \mathrm{R} \cdot \mathrm{T} /[\mathrm{X} \cdot(\mathrm{T}+\mathrm{R}-\mathrm{X})] .
\end{aligned}
$$

\subsubsection{Hexagonal model}

$\mathrm{S}_{\mathrm{T}}=$ area of measurement $=$ width of the window of measurement (ring width/20); $\mathrm{S}=$ mean cell area $=\mathrm{S}_{\mathrm{T}} /$ number of cells in the window of measurement; $x=$ mean cell wall width, with: s' = mean lumen area; $\mathrm{s}=$ mean cell wall area $=\mathrm{S}-\mathrm{s}$; $\mathrm{H}=$ height of the hexagon; $\mathrm{H}^{\prime}=\mathrm{H}-\mathrm{x}$.

As the angle between an axis passing by a corner of a hexagon and the adjacent median is of $30^{\circ}: \mathrm{S}=6 \mathrm{H} \cdot\left(\mathrm{H} \cdot \operatorname{tang} 30^{\circ}\right)$, as tang $30^{\circ}=$ $\sqrt{3} / 3$, thus $\mathrm{S}=2 \cdot \sqrt{3} \cdot \mathrm{H}^{2}$.

As well: $\mathrm{s}^{\prime}=2 \cdot \sqrt{3} \cdot \mathrm{H}^{\prime 2} ; \mathrm{s} / \mathrm{S}=\left(\mathrm{S}-\mathrm{s}^{\prime}\right) / \mathrm{S}=2 \cdot \sqrt{3} \cdot\left(\mathrm{H}^{2}-\mathrm{H}^{2}\right) /$ $\left(2 \cdot \sqrt{3} \cdot \mathrm{H}^{2}\right)=\left(\mathrm{H}^{2}-\mathrm{H}^{2}\right) / \mathrm{H}^{2}$.

And again, if $\mathrm{drx}=$ the wood density measured by $\mathrm{x}$ ray: apparent density of the cell wall $=\mathrm{drx} /$ cell wall proportion $=\mathrm{drx} \cdot \mathrm{S} / \mathrm{s}=\mathrm{drx}$. $\mathrm{H}^{2} /\left(\mathrm{H}^{2}-\mathrm{H}^{2}\right)$.

The use of rectangular and hexagonal models of cell shape allows the determination of the mean cell wall area, width and proportion. The cell wall apparent density is then obtained from the wood density/cell wall proportion ratio.

\subsection{Image analysis method}

Measurements were made on the same mounted sections as the planimetric method. Images of the rings were acquired at a magnification of 300 with a transmission microscope and by the use of Analysis ${ }^{\odot}$. At this magnification, the resolution of the images is $0.76 \mu \mathrm{m} / \mathrm{pixel}$. 
Table III. Planimetric and image analysis measurements on Finland spruce. Length of the window of measurement $=$ ring width $=2680 \mu \mathrm{m}$; width of the window of measurement for the planimetry $=3000 \mu \mathrm{m}$; width of the window of measurement for image analysis $=1000 \mu \mathrm{m}$; Rect. $=$ rectangular model - Hexag. $=$ hexagonal model - Masked $=$ masked images.

Finland spruce (FinS)

\begin{tabular}{|c|c|c|c|c|c|c|c|c|c|c|c|c|c|}
\hline \multirow{3}{*}{$\begin{array}{l}\text { Parts of } \\
\text { the ring }\end{array}$} & \multirow{3}{*}{$\begin{array}{c}\text { X-ray } \\
\left(\mathrm{kg} / \mathrm{m}^{3}\right)\end{array}$} & \multicolumn{8}{|c|}{ Planimetric measurements } & \multicolumn{4}{|c|}{ Image analysis } \\
\hline & & \multirow[t]{2}{*}{$\begin{array}{l}\text { Cell wall } \\
\text { widths } \\
(\mu \mathrm{m})\end{array}$} & \multirow[t]{2}{*}{$\begin{array}{l}\text { Radial } \phi \\
\qquad(\mu \mathrm{m})\end{array}$} & \multirow{2}{*}{$\begin{array}{l}\text { Tang } \phi \\
(\mu \mathrm{m})\end{array}$} & \multirow{2}{*}{$\begin{array}{c}\text { Cell wall } \\
\text { prop. } \\
\text { Rect. }\end{array}$} & \multirow{2}{*}{$\begin{array}{c}\text { Packing } \\
\text { density } \\
\left(\mathrm{kg} / \mathrm{m}^{3}\right) \\
\text { Rect. }\end{array}$} & \multirow[t]{2}{*}{$\begin{array}{c}\mathrm{H} \\
(\mu \mathrm{m})\end{array}$} & \multirow{2}{*}{$\begin{array}{c}\text { Cell wall } \\
\text { prop. } \\
\text { Hexag. }\end{array}$} & \multirow{2}{*}{$\begin{array}{c}\text { Packing } \\
\text { density } \\
\left(\mathrm{kg} / \mathrm{m}^{3}\right) \\
\text { Hexag. }\end{array}$} & \multirow[t]{2}{*}{$\begin{array}{l}\text { Cell wall } \\
\text { prop. }\end{array}$} & \multirow[t]{2}{*}{$\begin{array}{c}\text { Packing } \\
\text { density } \\
\left(\mathrm{kg} / \mathrm{m}^{3}\right)\end{array}$} & \multirow{2}{*}{$\begin{array}{l}\text { Cell wall } \\
\text { prop. } \\
\text { (Masked) }\end{array}$} & \multirow{2}{*}{$\begin{array}{r}\text { Packing } \\
\text { density } \\
\left(\mathrm{kg} / \mathrm{m}^{3}\right) \\
\text { (Masked) }\end{array}$} \\
\hline & & & & & & & & & & & & & \\
\hline 1 & 363 & 2.9 & 47.4 & 31.0 & 0.284 & 1277 & 20.6 & 0.260 & 1398 & 0.339 & 1070 & 0.312 & 1163 \\
\hline 2 & 285 & 2.8 & 48.2 & 30.8 & 0.278 & 1027 & 20.7 & 0.253 & 1127 & 0.347 & 821 & 0.329 & 867 \\
\hline 3 & 299 & 2.8 & 44.4 & 30.8 & 0.290 & 1032 & 19.9 & 0.266 & 1123 & 0.351 & 853 & 0.335 & 893 \\
\hline 4 & 307 & 2.9 & 40.6 & 30.8 & 0.303 & 1012 & 19.0 & 0.281 & 1092 & 0.356 & 863 & 0.342 & 898 \\
\hline 5 & 319 & 2.9 & 41.2 & 30.9 & 0.306 & 1043 & 19.2 & 0.283 & 1126 & 0.360 & 885 & 0.346 & 922 \\
\hline 6 & 317 & 3.0 & 40.1 & 30.1 & 0.315 & 1005 & 18.7 & 0.292 & 1085 & 0.367 & 863 & 0.351 & 903 \\
\hline 7 & 316 & 3.0 & 39.3 & 29.9 & 0.322 & 982 & 18.4 & 0.298 & 1059 & 0.368 & 858 & 0.352 & 898 \\
\hline 8 & 328 & 3.0 & 40.5 & 30.0 & 0.322 & 1019 & 18.7 & 0.298 & 1101 & 0.377 & 869 & 0.360 & 910 \\
\hline 9 & 340 & 3.1 & 39.2 & 29.4 & 0.333 & 1021 & 18.2 & 0.308 & 1102 & 0.420 & 810 & 0.401 & 847 \\
\hline 10 & 361 & 3.1 & 38.1 & 29.2 & 0.344 & 1049 & 17.9 & 0.319 & 1130 & 0.423 & 854 & 0.405 & 890 \\
\hline 11 & 397 & 3.2 & 36.6 & 29.1 & 0.356 & 1116 & 17.5 & 0.331 & 1199 & 0.449 & 885 & 0.429 & 926 \\
\hline 12 & 433 & 3.5 & 34.2 & 29.4 & 0.390 & 1109 & 17.0 & 0.365 & 1186 & 0.489 & 886 & 0.463 & 936 \\
\hline 13 & 455 & 3.7 & 33.6 & 29.0 & 0.417 & 1090 & 16.8 & 0.391 & 1164 & 0.512 & 889 & 0.484 & 939 \\
\hline 14 & 498 & 4.2 & 33.1 & 29.3 & 0.464 & 1074 & 16.7 & 0.435 & 1144 & 0.563 & 885 & 0.535 & 931 \\
\hline 15 & 554 & 4.2 & 32.1 & 29.1 & 0.475 & 1166 & 16.4 & 0.446 & 1241 & 0.576 & 962 & 0.553 & 1002 \\
\hline 16 & 642 & 4.9 & 29.5 & 29.7 & 0.555 & 1157 & 15.9 & 0.523 & 1227 & 0.638 & 1006 & 0.612 & 1050 \\
\hline 17 & 713 & 5.3 & 26.0 & 28.9 & 0.624 & 1143 & 14.7 & 0.589 & 1210 & 0.709 & 1005 & 0.689 & 1035 \\
\hline 18 & 765 & 5.7 & 25.3 & 29.2 & 0.669 & 1144 & 14.6 & 0.632 & 1211 & 0.764 & 1002 & 0.743 & 1029 \\
\hline 19 & 864 & 6.4 & 24.0 & 29.6 & 0.737 & 1173 & 14.3 & 0.696 & 1242 & 0.795 & 1087 & 0.776 & 1114 \\
\hline 20 & 867 & 5.8 & 19.1 & 31.1 & 0.756 & 1147 & 13.1 & 0.691 & 1254 & 0.884 & 980 & 0.873 & 993 \\
\hline Mean & 471 & 3.8 & 35.6 & 29.9 & 0.427 & 1089 & 17.4 & 0.398 & 1171 & 0.504 & 917 & 0.485 & 957 \\
\hline
\end{tabular}

The procedure of acquisition (adjustment of the microscope, its focal length and illumination) was tested and settled down to ensure its reproducibility.

The rings images have a radial size equal to the ring width and a tangential width of $1000 \mu \mathrm{m}$. Only the South Finland pine ring image has a width of $802 \mu \mathrm{m}$.

Before making any measurements on the rings images, those have to be binarized. A digital image is characterised by a grey level histogram which represents the number of pixels belonging to the 256 different grey level values (from 0 (black) to 255 (white)). The grey level histogram of a ring image is a bimodal curve consisting of a first peak of dark pixels (low grey level values) corresponding to matter (tracheids, ray cells and canals walls) and a second one of light pixels (high grey level values) corresponding to voids (lumens and pores). As matter has to be separated from voids, the rings images are binarized so that a grey level of 0 is applied on the pixels belonging to matter (for which the original grey levels are lower than the threshold value) and a grey level of 255 on the pixels belonging to the voids (for which the original grey levels are higher than the threshold value). This binarisation, meaning the choice of a threshold, is made by automatic thresholding with Labview ${ }^{\circledR}$ (National Instruments). The thresholding mode leading to the more realistic separation between material and lumen is chosen.

Each image is divided into 20 parts in the radial direction so that one threshold is applied to each of those ring parts. It is preferable to do the segmentation on parts of the image, rather than on the complete image of the ring at one time, since the grey levels of the lumens in the earlywood have a tendency to be brighter than in the latewood, in view of the differences between the architectures of early and latewood cells [5].

On each tangential pixels line of the binarized image the numbers of black pixels nbp (corresponding to matter) and white pixels nwp (corresponding to voids) are counted. The proportion of matter in area is then obtained from $n b p /(n b p+n w p)$.

This proportion of matter was measured at first on the images of the whole rings and then on images of tracheids only (on which the rays, canals and defects were excluded).

When measuring the proportion of matter on the whole images, the walls of tracheids, rays and canals are considered. The ratio wood density / proportion of matter gives thus a measure of the apparent density of the tracheids, rays and canals walls. When only the tracheids are considered, the tracheid wall proportion is measured and the apparent density of the tracheid wall calculated.

\section{RESULTS (TABS. III TO VIII)}

The density of wood increases all along the period of a growth ring as a consequence of anatomical and chemical modifications. The mean variation for the six studied rings is 
Table IV. Planimetric and image analysis measurements on France spruce. Length of the window of measurement $=$ ring width $=2850 \mu \mathrm{m}$; width of the window of measurement for the planimetry $=3000 \mu \mathrm{m}$; width of the window of measurement for image analysis $=1000 \mu \mathrm{m}$.

\begin{tabular}{|c|c|c|c|c|c|c|c|c|c|c|c|c|c|}
\hline \multicolumn{14}{|c|}{ France spruce (FraS) } \\
\hline \multirow[b]{2}{*}{$\begin{array}{l}\text { Parts of } \\
\text { the ring }\end{array}$} & \multirow[b]{2}{*}{$\begin{array}{c}\text { X-ray } \\
\left(\mathrm{kg} / \mathrm{m}^{3}\right)\end{array}$} & \multicolumn{8}{|c|}{ Planimetric measurements } & \multicolumn{4}{|c|}{ Image analysis } \\
\hline & & $\begin{array}{c}\text { Cell wall } \\
\text { widths } \\
(\mu \mathrm{m})\end{array}$ & $\begin{array}{l}\text { Radial } \phi \\
\quad(\mu \mathrm{m})\end{array}$ & $\begin{array}{l}\text { Tang } \phi \\
(\mu \mathrm{m})\end{array}$ & $\begin{array}{l}\text { Cell } \\
\text { wall } \\
\text { prop. } \\
\text { Rect. }\end{array}$ & $\begin{array}{c}\text { Packing } \\
\text { density } \\
\left(\mathrm{kg} / \mathrm{m}^{3}\right) \\
\text { Rect. }\end{array}$ & $\begin{array}{c}\mathrm{H} \\
(\mu \mathrm{m})\end{array}$ & $\begin{array}{c}\text { Cell } \\
\text { wall } \\
\text { prop. } \\
\text { Hexag. }\end{array}$ & $\begin{array}{c}\text { Packing } \\
\text { density } \\
\left(\mathrm{kg} / \mathrm{m}^{3}\right) \\
\text { Hexag. }\end{array}$ & $\begin{array}{l}\text { Cell } \\
\text { wall } \\
\text { prop. }\end{array}$ & $\begin{array}{c}\text { Packing } \\
\text { density } \\
\left(\mathrm{kg} / \mathrm{m}^{3}\right)\end{array}$ & $\begin{array}{c}\text { Cell } \\
\text { wall } \\
\text { prop. } \\
\text { (Masked) }\end{array}$ & $\begin{array}{c}\text { Packing } \\
\text { density } \\
\left(\mathrm{kg} / \mathrm{m}^{3}\right) \\
\text { (Masked) }\end{array}$ \\
\hline 1 & 351 & 3.1 & 41.4 & 32.8 & 0.309 & 1136 & 19.8 & 0.287 & 1222 & 0.346 & 1015 & 0.319 & 1100 \\
\hline 2 & 286 & 2.8 & 42.0 & 33.2 & 0.284 & 1005 & 20.0 & 0.264 & 1082 & 0.341 & 839 & 0.322 & 889 \\
\hline 3 & 289 & 2.9 & 39.2 & 33.3 & 0.293 & 986 & 19.4 & 0.273 & 1057 & 0.352 & 820 & 0.330 & 875 \\
\hline 4 & 288 & 2.9 & 38.7 & 33.7 & 0.295 & 977 & 19.4 & 0.275 & 1046 & 0.358 & 804 & 0.343 & 839 \\
\hline 5 & 300 & 2.9 & 36.9 & 33.6 & 0.307 & 977 & 18.9 & 0.287 & 1045 & 0.365 & 822 & 0.349 & 860 \\
\hline 6 & 306 & 3.0 & 35.8 & 33.2 & 0.315 & 971 & 18.5 & 0.295 & 1037 & 0.364 & 840 & 0.348 & 878 \\
\hline 7 & 318 & 3.2 & 40.1 & 32.9 & 0.325 & 979 & 19.5 & 0.303 & 1050 & 0.374 & 850 & 0.360 & 884 \\
\hline 8 & 338 & 3.5 & 41.0 & 32.1 & 0.352 & 960 & 19.5 & 0.327 & 1032 & 0.385 & 878 & 0.371 & 911 \\
\hline 9 & 364 & 3.7 & 39.9 & 31.9 & 0.372 & 979 & 19.2 & 0.346 & 1051 & 0.411 & 885 & 0.395 & 922 \\
\hline 10 & 396 & 3.7 & 36.5 & 31.6 & 0.391 & 1013 & 18.3 & 0.366 & 1083 & 0.435 & 909 & 0.423 & 937 \\
\hline 11 & 420 & 4.2 & 34.1 & 31.3 & 0.448 & 937 & 17.6 & 0.421 & 998 & 0.448 & 937 & 0.438 & 960 \\
\hline 12 & 442 & 4.1 & 35.6 & 31.6 & 0.427 & 1036 & 18.0 & 0.400 & 1105 & 0.469 & 943 & 0.458 & 965 \\
\hline 13 & 456 & 4.3 & 36.0 & 31.1 & 0.446 & 1023 & 18.0 & 0.418 & 1091 & 0.470 & 971 & 0.459 & 993 \\
\hline 14 & 479 & 4.3 & 36.0 & 31.5 & 0.446 & 1075 & 18.1 & 0.418 & 1146 & 0.487 & 983 & 0.478 & 1003 \\
\hline 15 & 516 & 4.8 & 34.2 & 31.6 & 0.496 & 1040 & 17.7 & 0.467 & 1106 & 0.520 & 992 & 0.509 & 1015 \\
\hline 16 & 592 & 5.1 & 30.9 & 31.0 & 0.549 & 1078 & 16.6 & 0.518 & 1142 & 0.578 & 1024 & 0.568 & 1043 \\
\hline 17 & 685 & 5.2 & 27.5 & 30.8 & 0.593 & 1156 & 15.6 & 0.559 & 1225 & 0.647 & 1058 & 0.636 & 1077 \\
\hline 18 & 827 & 5.8 & 26.0 & 30.5 & 0.662 & 1250 & 15.1 & 0.625 & 1324 & 0.731 & 1131 & 0.725 & 1141 \\
\hline 19 & 962 & 6.1 & 22.6 & 31.2 & 0.721 & 1334 & 14.3 & 0.674 & 1428 & 0.803 & 1198 & 0.797 & 1208 \\
\hline 20 & 1027 & 6.1 & 19.2 & 32.5 & 0.776 & 1323 & 13.4 & 0.706 & 1455 & 0.869 & 1181 & 0.865 & 1188 \\
\hline Mean & 482 & 4.1 & 34.7 & 32.1 & 0.440 & 1062 & 17.8 & 0.411 & 1136 & 0.488 & 954 & 0.475 & 984 \\
\hline
\end{tabular}

a LW (latewood) density about 3 times greater than the EW (earlywood) density, that is in the range of the 1 to 4 times variation already reported [16]. The evolution of density is also more abrupt in the LW [28].

\subsection{Planimetric method}

Based upon (i) the anatomical measurements and (ii) the geometric model, the intra ring density variation is readily displayed in order to compare with the measured X-ray density profile. For the six rings, when multiplying the calculated cell wall proportion with the accepted cell wall density value of $1530 \mathrm{~kg} / \mathrm{m}^{3}$ [36], the obtained wood density profile is higher than the measured one (Fig. 2). The use of a rectangular model leads to higher cell wall proportion, thus an even higher calculated wood density than the hexagonal one due to mathematical considerations. It seems preferable to use the hexagonal model as it also fits the real tracheid shape better.

The calculated apparent densities of the cell wall vary along the six rings between 1030 and $1460 \mathrm{~kg} / \mathrm{m}^{3}$, values quite far from $1530 \mathrm{~kg} / \mathrm{m}^{3}$. Those densities vary from EW (mean value for the six rings of $1140 \mathrm{~kg} / \mathrm{m}^{3}$ ) to LW (mean value of $1360 \mathrm{~kg} / \mathrm{m}^{3}$ ).
This increase of the apparent density of the cell wall shows that the cell wall proportion alone (rendering the anatomical variations) is not responsible of the entire wood density increase from EW to LW.

\subsection{Image analysis method}

As with planimetry, the wood density is over estimated when applying a density of $1530 \mathrm{~kg} / \mathrm{m}^{3}$ to the measured cell wall proportion (Fig. 3). The exclusion of rays and canals smoothes the measurements as it excludes local characteristics. This is illustrated on Figure 4. On this figure we have reported the X-ray wood density measurement and the wood density profiles calculated by the mean of the cell wall proportion obtained by image analysis of the sections. The cell wall proportion is measured (i) for the whole image (tracheids and resin canals) and measured (ii) for tracheids only. For all the rings but especially the FraS sample (Fig. 5), the exclusion decreases the measured proportion of matter, especially in the earlywood.

The calculated apparent densities of (tracheids, rays and canals) walls vary between 880 in the EW and $1140 \mathrm{~kg} / \mathrm{m}^{3}$ in the LW and the apparent densities of the tracheids walls range from 940 to $1150 \mathrm{~kg} / \mathrm{m}^{3}$, values again quite far from $1530 \mathrm{~kg} / \mathrm{m}^{3}$. 


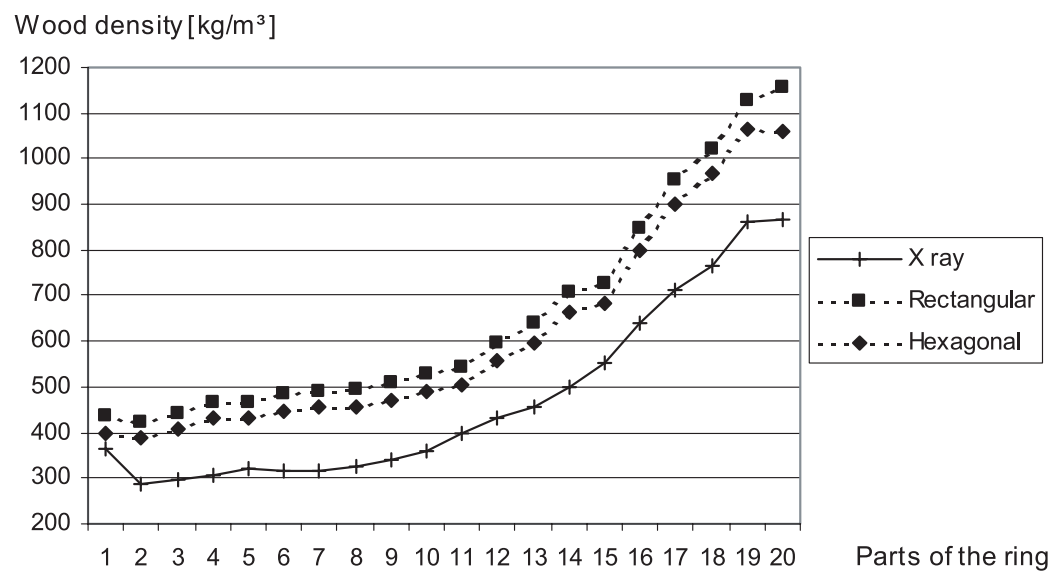

Figure 2. Finland spruce ring: Wood density measured by X-ray and calculated from the cell wall proportion (rectangular and hexagonal model) and a cell wall density of $1530 \mathrm{~kg} / \mathrm{m}^{3}$.

Table V. Planimetric and image analysis measurements on France pine. Length of the window of measurement $=$ ring width $=2690 \mu \mathrm{m} ;$ width of the window of measurement for the planimetry $=1500 \mu \mathrm{m}$; width of the window of measurement for image analysis $=1000 \mu \mathrm{m}$.

\begin{tabular}{|c|c|c|c|c|c|c|c|c|c|c|c|c|c|}
\hline \multicolumn{14}{|c|}{ France fir $(\mathrm{FraF})$} \\
\hline \multirow[b]{2}{*}{$\begin{array}{l}\text { Parts of } \\
\text { the ring }\end{array}$} & \multirow[b]{2}{*}{$\begin{array}{c}\text { X-ray } \\
\left(\mathrm{kg} / \mathrm{m}^{3}\right)\end{array}$} & \multicolumn{8}{|c|}{ Planimetric measurements } & \multicolumn{4}{|c|}{ Image analysis } \\
\hline & & $\begin{array}{c}\text { Cell wall } \\
\text { widths } \\
(\mu \mathrm{m})\end{array}$ & $\begin{array}{l}\text { Radial } \phi \\
\qquad(\mu \mathrm{m})\end{array}$ & $\begin{array}{c}\text { Tang } \phi \\
(\mu \mathrm{m})\end{array}$ & $\begin{array}{l}\text { Cell } \\
\text { wall } \\
\text { prop. } \\
\text { Rect. }\end{array}$ & $\begin{array}{c}\text { Packing } \\
\text { density } \\
\left(\mathrm{kg} / \mathrm{m}^{3}\right) \\
\text { Rect. }\end{array}$ & $\begin{array}{c}\mathrm{H} \\
(\mu \mathrm{m})\end{array}$ & $\begin{array}{c}\text { Cell } \\
\text { wall } \\
\text { prop. } \\
\text { Hexag. }\end{array}$ & $\begin{array}{c}\text { Packing } \\
\text { density } \\
\left(\mathrm{kg} / \mathrm{m}^{3}\right) \\
\text { Hexag. }\end{array}$ & $\begin{array}{l}\text { Cell } \\
\text { wall } \\
\text { prop. }\end{array}$ & $\begin{array}{c}\text { Packing } \\
\text { density } \\
\left(\mathrm{kg} / \mathrm{m}^{3}\right)\end{array}$ & $\begin{array}{c}\text { Cell } \\
\text { wall } \\
\text { prop. } \\
\text { (Masked) }\end{array}$ & $\begin{array}{c}\text { Packing } \\
\text { density } \\
\left(\mathrm{kg} / \mathrm{m}^{3}\right) \\
\text { (Masked) }\end{array}$ \\
\hline 1 & 330 & 2.6 & 42.9 & 29.2 & 0.282 & 1172 & 19.0 & 0.258 & 1277 & 0.343 & 963 & 0.301 & 1097 \\
\hline 2 & 287 & 2.5 & 43.2 & 29.6 & 0.262 & 1096 & 19.2 & 0.240 & 1194 & 0.322 & 892 & 0.288 & 995 \\
\hline 3 & 286 & 2.5 & 42.7 & 29.9 & 0.266 & 1077 & 19.2 & 0.244 & 1171 & 0.321 & 892 & 0.291 & 982 \\
\hline 4 & 303 & 2.6 & 42.6 & 29.9 & 0.271 & 1117 & 19.2 & 0.250 & 1214 & 0.332 & 914 & 0.302 & 1003 \\
\hline 5 & 314 & 2.7 & 41.9 & 30.9 & 0.277 & 1133 & 19.3 & 0.256 & 1225 & 0.331 & 947 & 0.300 & 1045 \\
\hline 6 & 327 & 2.8 & 40.9 & 31.2 & 0.291 & 1123 & 19.2 & 0.270 & 1212 & 0.357 & 917 & 0.329 & 995 \\
\hline 7 & 337 & 3.0 & 41.6 & 30.8 & 0.307 & 1096 & 19.2 & 0.284 & 1185 & 0.362 & 930 & 0.333 & 1012 \\
\hline 8 & 351 & 3.1 & 39.3 & 30.5 & 0.332 & 1058 & 18.6 & 0.308 & 1139 & 0.378 & 928 & 0.347 & 1011 \\
\hline 9 & 382 & 3.2 & 35.9 & 30.4 & 0.350 & 1092 & 17.7 & 0.327 & 1169 & 0.398 & 959 & 0.366 & 1043 \\
\hline 10 & 420 & 3.4 & 36.1 & 30.7 & 0.366 & 1147 & 17.9 & 0.342 & 1227 & 0.431 & 974 & 0.401 & 1048 \\
\hline 11 & 453 & 3.6 & 34.8 & 30.7 & 0.395 & 1148 & 17.6 & 0.369 & 1226 & 0.465 & 974 & 0.435 & 1041 \\
\hline 12 & 505 & 3.9 & 31.5 & 30.6 & 0.436 & 1157 & 16.7 & 0.410 & 1232 & 0.510 & 990 & 0.486 & 1039 \\
\hline 13 & 552 & 4.2 & 30.5 & 31.2 & 0.475 & 1162 & 16.6 & 0.447 & 1235 & 0.539 & 1024 & 0.516 & 1071 \\
\hline 14 & 620 & 4.6 & 27.6 & 30.5 & 0.532 & 1166 & 15.6 & 0.500 & 1239 & 0.598 & 1037 & 0.573 & 1081 \\
\hline 15 & 700 & 4.7 & 25.8 & 29.0 & 0.574 & 1219 & 14.7 & 0.541 & 1294 & 0.647 & 1082 & 0.624 & 1122 \\
\hline 16 & 716 & 4.8 & 26.5 & 29.4 & 0.574 & 1248 & 15.0 & 0.541 & 1324 & 0.651 & 1100 & 0.626 & 1143 \\
\hline 17 & 783 & 5.1 & 23.7 & 28.9 & 0.633 & 1237 & 14.0 & 0.595 & 1315 & 0.711 & 1102 & 0.688 & 1138 \\
\hline 18 & 814 & 5.3 & 24.0 & 28.4 & 0.648 & 1257 & 14.0 & 0.610 & 1334 & 0.740 & 1100 & 0.716 & 1137 \\
\hline 19 & 842 & 5.3 & 22.6 & 28.6 & 0.667 & 1262 & 13.7 & 0.627 & 1343 & 0.730 & 1154 & 0.704 & 1196 \\
\hline 20 & 861 & 5.1 & 18.3 & 28.7 & 0.712 & 1209 & 12.3 & 0.654 & 1316 & 0.770 & 1119 & 0.750 & 1148 \\
\hline Mean & 509 & 3.8 & 33.6 & 30.0 & 0.432 & 1159 & 16.9 & 0.404 & 1244 & 0.497 & 1000 & 0.469 & 1067 \\
\hline
\end{tabular}


Table VI. Planimetric and image analysis measurements on France pine. Length of the window of measurement $=$ ring width $=2690 \mu$ m; width of the window of measurement for the planimetry $=1500 \mu \mathrm{m}$; width of the window of measurement for image analysis $=1000 \mu \mathrm{m}$.

\begin{tabular}{|c|c|c|c|c|c|c|c|c|c|c|c|c|c|}
\hline \multicolumn{14}{|c|}{ France pine (FraP) } \\
\hline \multirow[b]{2}{*}{$\begin{array}{l}\text { Parts of } \\
\text { the ring }\end{array}$} & \multirow[b]{2}{*}{$\begin{array}{c}\text { X-ray } \\
\left(\mathrm{kg} / \mathrm{m}^{3}\right)\end{array}$} & \multicolumn{8}{|c|}{ Planimetric measurements } & \multicolumn{4}{|c|}{ Image analysis } \\
\hline & & $\begin{array}{l}\text { Cell wall } \\
\text { widths } \\
(\mu \mathrm{m})\end{array}$ & $\begin{array}{l}\text { Radial } \phi \\
\qquad(\mu \mathrm{m})\end{array}$ & $\begin{array}{c}\text { Tang } \phi \\
(\mu \mathrm{m})\end{array}$ & $\begin{array}{l}\text { Cell } \\
\text { wall } \\
\text { prop. } \\
\text { Rect. }\end{array}$ & $\begin{array}{c}\text { Packing } \\
\text { density } \\
\left(\mathrm{kg} / \mathrm{m}^{3}\right) \\
\text { Rect. }\end{array}$ & $\begin{array}{c}\mathrm{H} \\
(\mu \mathrm{m})\end{array}$ & $\begin{array}{c}\text { Cell } \\
\text { wall } \\
\text { prop. } \\
\text { Hexag. }\end{array}$ & $\begin{array}{c}\text { Packing } \\
\text { density } \\
\left(\mathrm{kg} / \mathrm{m}^{3}\right) \\
\text { Hexag. }\end{array}$ & $\begin{array}{l}\text { Cell } \\
\text { wall } \\
\text { prop. }\end{array}$ & $\begin{array}{c}\text { Packing } \\
\text { density } \\
\left(\mathrm{kg} / \mathrm{m}^{3}\right)\end{array}$ & $\begin{array}{c}\text { Cell } \\
\text { wall } \\
\text { prop. } \\
\text { (Masked) }\end{array}$ & $\begin{array}{c}\text { Packing } \\
\text { density } \\
\left(\mathrm{kg} / \mathrm{m}^{3}\right) \\
\text { (Masked) }\end{array}$ \\
\hline 1 & 417 & 3.4 & 40.9 & 29.7 & 0.354 & 1178 & 18.7 & 0.327 & 1274 & 0.380 & 1098 & 0.367 & 1137 \\
\hline 2 & 325 & 3.3 & 48.0 & 30.0 & 0.324 & 1002 & 20.4 & 0.295 & 1102 & 0.355 & 915 & 0.345 & 941 \\
\hline 3 & 309 & 3.1 & 47.0 & 29.7 & 0.311 & 995 & 20.1 & 0.283 & 1093 & 0.366 & 843 & 0.361 & 855 \\
\hline 4 & 319 & 3.2 & 46.7 & 29.7 & 0.321 & 995 & 20.0 & 0.292 & 1092 & 0.354 & 902 & 0.355 & 898 \\
\hline 5 & 324 & 3.2 & 45.3 & 29.9 & 0.323 & 1004 & 19.8 & 0.295 & 1097 & 0.351 & 923 & 0.350 & 926 \\
\hline 6 & 324 & 3.2 & 44.4 & 29.6 & 0.327 & 991 & 19.5 & 0.299 & 1082 & 0.362 & 894 & 0.353 & 918 \\
\hline 7 & 312 & 3.2 & 47.7 & 29.6 & 0.320 & 975 & 20.2 & 0.291 & 1073 & 0.330 & 945 & 0.328 & 951 \\
\hline 8 & 307 & 3.0 & 45.0 & 29.6 & 0.313 & 981 & 19.6 & 0.286 & 1072 & 0.356 & 862 & 0.357 & 859 \\
\hline 9 & 317 & 3.2 & 44.9 & 29.9 & 0.323 & 981 & 19.7 & 0.296 & 1071 & 0.373 & 850 & 0.365 & 869 \\
\hline 10 & 353 & 3.3 & 39.3 & 30.1 & 0.347 & 1017 & 18.5 & 0.322 & 1096 & 0.405 & 872 & 0.395 & 895 \\
\hline 11 & 426 & 3.8 & 38.1 & 30.2 & 0.397 & 1073 & 18.2 & 0.370 & 1152 & 0.458 & 930 & 0.453 & 940 \\
\hline 12 & 509 & 4.6 & 36.9 & 31.9 & 0.466 & 1093 & 18.4 & 0.437 & 1165 & 0.534 & 953 & 0.527 & 966 \\
\hline 13 & 583 & 5.1 & 32.2 & 33.0 & 0.530 & 1100 & 17.5 & 0.499 & 1167 & 0.611 & 955 & 0.603 & 966 \\
\hline 14 & 569 & 4.9 & 30.0 & 32.3 & 0.531 & 1071 & 16.7 & 0.500 & 1137 & 0.641 & 888 & 0.634 & 898 \\
\hline 15 & 709 & 5.4 & 28.5 & 30.0 & 0.599 & 1184 & 15.7 & 0.566 & 1253 & 0.659 & 1076 & 0.662 & 1071 \\
\hline 16 & 824 & 6.3 & 26.7 & 31.3 & 0.682 & 1208 & 15.5 & 0.644 & 1279 & 0.747 & 1102 & 0.745 & 1106 \\
\hline 17 & 882 & 6.3 & 27.9 & 28.3 & 0.698 & 1264 & 15.1 & 0.662 & 1332 & 0.779 & 1132 & 0.777 & 1135 \\
\hline 18 & 925 & 6.6 & 26.8 & 29.0 & 0.722 & 1281 & 15.0 & 0.685 & 1349 & 0.794 & 1166 & 0.799 & 1157 \\
\hline 19 & 939 & 6.6 & 27.0 & 28.0 & 0.731 & 1285 & 14.8 & 0.695 & 1351 & 0.814 & 1154 & 0.819 & 1146 \\
\hline 20 & 862 & 5.7 & 22.2 & 28.4 & 0.708 & 1218 & 13.5 & 0.666 & 1295 & 0.777 & 1110 & 0.794 & 1086 \\
\hline Mean & 527 & 4.4 & 37.3 & 30.0 & 0.466 & 1095 & 17.8 & 0.436 & 1177 & 0.522 & 979 & 0.520 & 986 \\
\hline
\end{tabular}

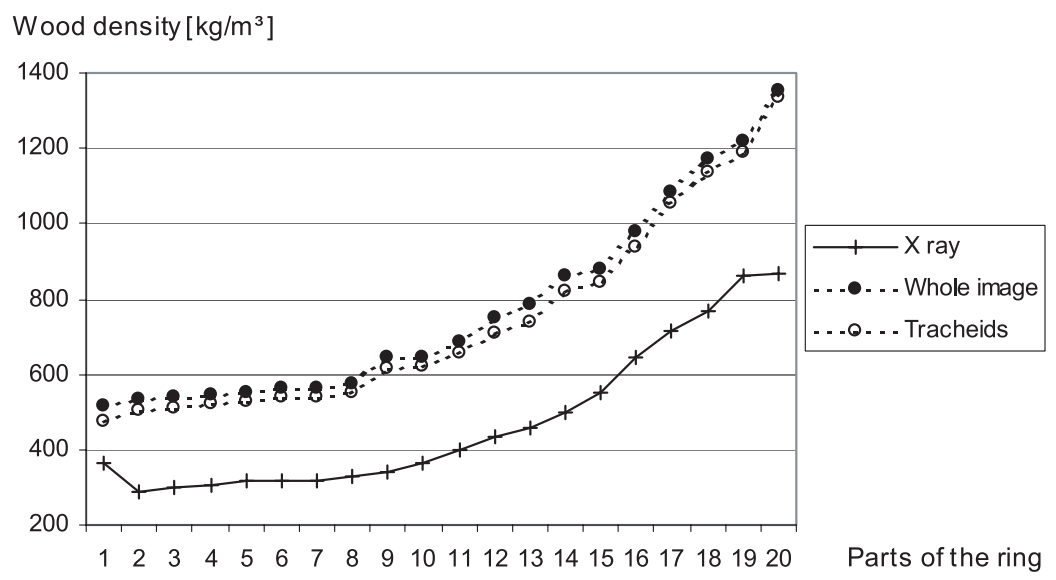

Figure 3. Finland spruce ring: Wood density measured by X-ray and calculated from the cell wall proportion (analysis of the whole image and tracheids only) and a cell wall density of $1530 \mathrm{~kg} / \mathrm{m}^{3}$. 


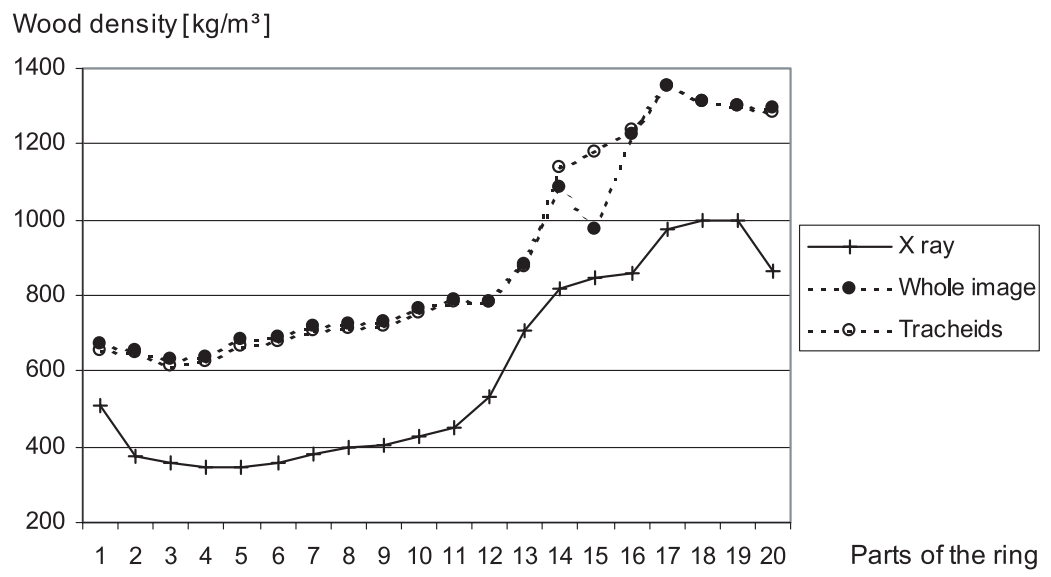

Figure 4. South Finland pine ring: Wood density measured by X-ray and calculated from the cell wall proportion (analysis of the whole image and tracheids only) and a cell wall density of $1530 \mathrm{~kg} / \mathrm{m}^{3}$.

Table VII. Planimetric and image analysis measurements on North Finland pine. Length of the window of measurement $=$ ring width $=$ $1280 \mu \mathrm{m}$; width of the window of measurement for the planimetry $=1000 \mu \mathrm{m}$; width of the window of measurement for image analysis $=$ $1000 \mu \mathrm{m}$.

\begin{tabular}{|c|c|c|c|c|c|c|c|c|c|c|c|c|c|}
\hline \multicolumn{14}{|c|}{ North Finland pine (NFinP) } \\
\hline \multirow[b]{2}{*}{$\begin{array}{l}\text { Parts of } \\
\text { the ring }\end{array}$} & \multirow[b]{2}{*}{$\begin{array}{c}\text { X-ray } \\
\left(\mathrm{kg} / \mathrm{m}^{3}\right)\end{array}$} & \multicolumn{8}{|c|}{ Planimetric measurements } & \multicolumn{4}{|c|}{ Image analysis } \\
\hline & & $\begin{array}{l}\text { Cell wall } \\
\text { widths } \\
(\mu \mathrm{m})\end{array}$ & $\begin{array}{l}\text { Radial } \phi \\
\qquad(\mu \mathrm{m})\end{array}$ & $\begin{array}{l}\text { Tang } \phi \\
(\mu \mathrm{m})\end{array}$ & $\begin{array}{l}\text { Cell } \\
\text { wall } \\
\text { prop. } \\
\text { Rect. }\end{array}$ & $\begin{array}{c}\text { Packing } \\
\text { density } \\
\left(\mathrm{kg} / \mathrm{m}^{3}\right) \\
\text { Rect. }\end{array}$ & $\begin{array}{c}\mathrm{H} \\
(\mu \mathrm{m})\end{array}$ & $\begin{array}{c}\text { Cell } \\
\text { wall } \\
\text { prop. } \\
\text { Hexag. }\end{array}$ & $\begin{array}{c}\text { Packing } \\
\text { density } \\
\left(\mathrm{kg} / \mathrm{m}^{3}\right) \\
\text { Hexag. }\end{array}$ & $\begin{array}{l}\text { Cell } \\
\text { wall } \\
\text { prop. }\end{array}$ & $\begin{array}{l}\text { Packing } \\
\text { density } \\
\left(\mathrm{kg} / \mathrm{m}^{3}\right)\end{array}$ & $\begin{array}{c}\text { Cell } \\
\text { wall } \\
\text { prop. } \\
\text { (Masked) }\end{array}$ & $\begin{array}{c}\text { Packing } \\
\text { density } \\
\left(\mathrm{kg} / \mathrm{m}^{3}\right) \\
\text { (Masked) }\end{array}$ \\
\hline 1 & 433 & 3.8 & 35.1 & 28.1 & 0.353 & 1228 & 16.9 & 0.328 & 1319 & 0.419 & 1035 & 0.409 & 1057 \\
\hline 2 & 371 & 3.6 & 35.3 & 27.4 & 0.334 & 1110 & 16.7 & 0.310 & 1196 & 0.423 & 876 & 0.416 & 893 \\
\hline 3 & 352 & 3.5 & 36.9 & 27.9 & 0.323 & 1089 & 17.2 & 0.300 & 1175 & 0.444 & 792 & 0.437 & 806 \\
\hline 4 & 361 & 3.4 & 37.4 & 28.4 & 0.328 & 1102 & 17.5 & 0.304 & 1188 & 0.446 & 809 & 0.438 & 823 \\
\hline 5 & 362 & 3.4 & 37.8 & 27.2 & 0.340 & 1064 & 17.2 & 0.314 & 1153 & 0.447 & 809 & 0.442 & 818 \\
\hline 6 & 354 & 3.6 & 37.2 & 28.0 & 0.341 & 1038 & 17.3 & 0.316 & 1120 & 0.458 & 772 & 0.456 & 776 \\
\hline 7 & 366 & 3.8 & 39.2 & 28.0 & 0.347 & 1053 & 17.8 & 0.321 & 1141 & 0.458 & 799 & 0.456 & 803 \\
\hline 8 & 376 & 3.9 & 42.1 & 28.0 & 0.350 & 1074 & 18.4 & 0.321 & 1172 & 0.448 & 840 & 0.445 & 844 \\
\hline 9 & 375 & 4.0 & 39.7 & 28.0 & 0.362 & 1037 & 17.9 & 0.333 & 1125 & 0.468 & 801 & 0.466 & 804 \\
\hline 10 & 378 & 4.1 & 37.8 & 28.4 & 0.362 & 1045 & 17.6 & 0.335 & 1127 & 0.470 & 805 & 0.468 & 807 \\
\hline 11 & 396 & 4.2 & 39.0 & 28.4 & 0.374 & 1058 & 17.9 & 0.346 & 1144 & 0.498 & 795 & 0.493 & 804 \\
\hline 12 & 425 & 4.6 & 35.1 & 28.4 & 0.412 & 1032 & 16.9 & 0.384 & 1106 & 0.523 & 813 & 0.518 & 821 \\
\hline 13 & 479 & 5.6 & 35.2 & 28.3 & 0.443 & 1082 & 17.0 & 0.413 & 1159 & 0.549 & 873 & 0.542 & 884 \\
\hline 14 & 530 & 6.1 & 33.9 & 28.3 & 0.473 & 1119 & 16.6 & 0.443 & 1196 & 0.608 & 872 & 0.603 & 879 \\
\hline 15 & 628 & 6.3 & 28.5 & 28.6 & 0.542 & 1160 & 15.4 & 0.511 & 1230 & 0.701 & 896 & 0.692 & 907 \\
\hline 16 & 746 & 6.1 & 24.7 & 27.5 & 0.655 & 1139 & 14.0 & 0.620 & 1204 & 0.708 & 1053 & 0.782 & 953 \\
\hline 17 & 826 & 6.9 & 23.1 & 27.1 & 0.715 & 1155 & 13.4 & 0.677 & 1221 & 0.731 & 1130 & 0.859 & 961 \\
\hline 18 & 921 & 6.9 & 23.1 & 27.5 & 0.726 & 1269 & 13.5 & 0.686 & 1342 & 0.821 & 1121 & 0.843 & 1093 \\
\hline 19 & 959 & 6.6 & 22.4 & 26.6 & 0.744 & 1288 & 13.1 & 0.705 & 1360 & 0.806 & 1190 & 0.800 & 1199 \\
\hline 20 & 875 & 5.8 & 19.4 & 27.0 & 0.659 & 1328 & 12.3 & 0.613 & 1427 & 0.734 & 1192 & 0.726 & 1205 \\
\hline Mean & 526 & 4.8 & 33.2 & 27.8 & 0.459 & 1124 & 16.2 & 0.429 & 1205 & 0.558 & 914 & 0.565 & 907 \\
\hline
\end{tabular}




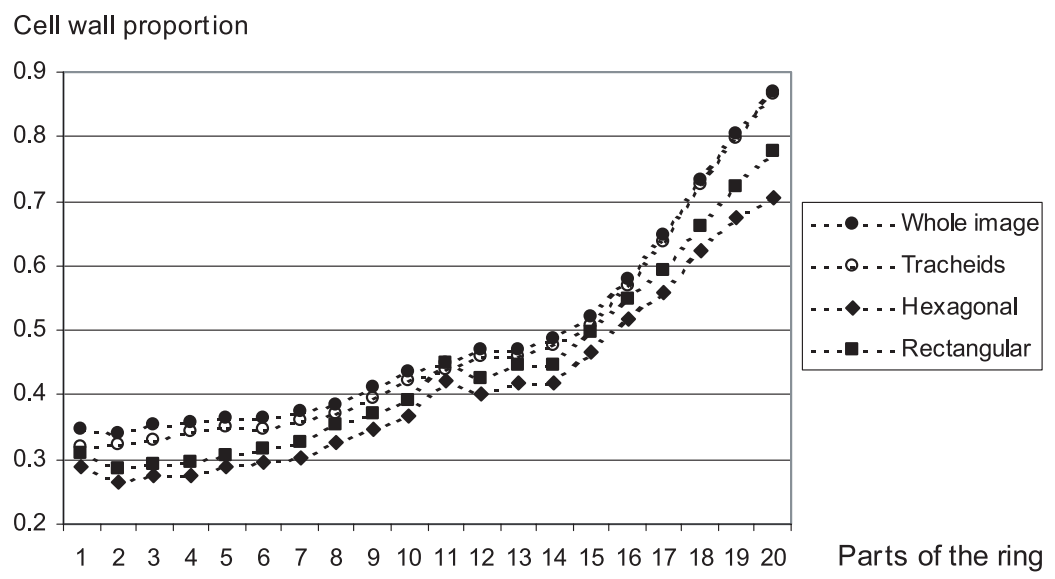

Figure 5. France spruce ring: Cell wall proportion calculated from the rectangular and hexagonal models and measured with image analysis (analysis of the whole image and tracheids only).

Table VIII. Planimetric and image analysis measurements on South Finland pine. Length of the window of measurement $=$ ring width $=$ $2070 \mu \mathrm{m}$; width of the window of measurement for the planimetry $=1500 \mu \mathrm{m}$; width of the window of measurement for image analysis $=$ $802 \mu \mathrm{m}$.

\begin{tabular}{|c|c|c|c|c|c|c|c|c|c|c|c|c|c|}
\hline \multicolumn{14}{|c|}{ South Finland Pine (SFinP) } \\
\hline \multirow{2}{*}{$\begin{array}{l}\text { Parts of } \\
\text { the ring }\end{array}$} & \multirow{2}{*}{$\begin{array}{c}\text { X-ray } \\
\left(\mathrm{kg} / \mathrm{m}^{3}\right)\end{array}$} & \multicolumn{8}{|c|}{ Planimetric measurements } & \multicolumn{4}{|c|}{ Image analysis } \\
\hline & & $\begin{array}{c}\text { Cell } \\
\text { wall } \\
\text { widths } \\
(\mu \mathrm{m})\end{array}$ & $\begin{array}{l}\text { Radial } \phi \\
(\mu \mathrm{m})\end{array}$ & $\begin{array}{c}\text { Tang } \phi \\
(\mu \mathrm{m})\end{array}$ & $\begin{array}{l}\text { Cell } \\
\text { wall } \\
\text { prop. } \\
\text { Rect. }\end{array}$ & $\begin{array}{c}\text { Packing } \\
\text { density } \\
\left(\mathrm{kg} / \mathrm{m}^{3}\right) \\
\text { Rect. }\end{array}$ & $\begin{array}{c}\mathrm{H} \\
(\mu \mathrm{m})\end{array}$ & $\begin{array}{c}\text { Cell } \\
\text { wall } \\
\text { prop. } \\
\text { Hexag. }\end{array}$ & $\begin{array}{c}\text { Packing } \\
\text { density } \\
\left(\mathrm{kg} / \mathrm{m}^{3}\right) \\
\text { Hexag. }\end{array}$ & $\begin{array}{l}\text { Cell } \\
\text { wall } \\
\text { prop. }\end{array}$ & $\begin{array}{c}\text { Packing } \\
\text { density } \\
\left(\mathrm{kg} / \mathrm{m}^{3}\right)\end{array}$ & $\begin{array}{c}\text { Cell } \\
\text { wall } \\
\text { prop. } \\
\text { (Masked) }\end{array}$ & $\begin{array}{c}\text { Packing } \\
\text { density } \\
\left(\mathrm{kg} / \mathrm{m}^{3}\right) \\
\text { (Masked) }\end{array}$ \\
\hline 1 & 508 & 3.0 & 38.8 & 30.4 & 0.396 & 1281 & 18.4 & 0.369 & 1377 & 0.441 & 1152 & 0.426 & 1193 \\
\hline 2 & 374 & 2.8 & 43.3 & 30.7 & 0.366 & 1021 & 19.6 & 0.338 & 1107 & 0.429 & 872 & 0.423 & 883 \\
\hline 3 & 355 & 2.8 & 43.6 & 31.6 & 0.350 & 1016 & 20.0 & 0.323 & 1099 & 0.413 & 859 & 0.402 & 884 \\
\hline 4 & 346 & 2.9 & 39.0 & 31.2 & 0.359 & 964 & 18.8 & 0.334 & 1035 & 0.418 & 828 & 0.408 & 847 \\
\hline 5 & 348 & 3.0 & 38.9 & 30.9 & 0.360 & 968 & 18.6 & 0.335 & 1039 & 0.445 & 782 & 0.435 & 801 \\
\hline 6 & 360 & 3.0 & 41.3 & 30.6 & 0.365 & 986 & 19.1 & 0.338 & 1064 & 0.451 & 798 & 0.442 & 815 \\
\hline 7 & 383 & 3.1 & 39.6 & 30.0 & 0.395 & 968 & 18.5 & 0.367 & 1043 & 0.469 & 817 & 0.462 & 829 \\
\hline 8 & 398 & 3.2 & 38.4 & 30.2 & 0.407 & 979 & 18.3 & 0.379 & 1051 & 0.473 & 841 & 0.465 & 856 \\
\hline 9 & 406 & 3.3 & 39.6 & 30.1 & 0.413 & 983 & 18.6 & 0.384 & 1057 & 0.478 & 849 & 0.468 & 867 \\
\hline 10 & 427 & 3.2 & 36.8 & 30.6 & 0.428 & 998 & 18.0 & 0.400 & 1067 & 0.499 & 856 & 0.491 & 870 \\
\hline 11 & 453 & 3.4 & 35.8 & 30.3 & 0.448 & 1011 & 17.7 & 0.419 & 1080 & 0.517 & 877 & 0.512 & 884 \\
\hline 12 & 530 & 3.6 & 35.8 & 29.5 & 0.489 & 1085 & 17.5 & 0.457 & 1159 & 0.513 & 1034 & 0.512 & 1036 \\
\hline 13 & 706 & 4.0 & 32.8 & 29.6 & 0.594 & 1188 & 16.7 & 0.560 & 1260 & 0.577 & 1223 & 0.573 & 1232 \\
\hline 14 & 817 & 4.2 & 27.8 & 29.9 & 0.667 & 1225 & 15.5 & 0.632 & 1293 & 0.710 & 1151 & 0.742 & 1101 \\
\hline 15 & 845 & 4.6 & 27.0 & 28.5 & 0.705 & 1199 & 14.9 & 0.669 & 1263 & 0.636 & 1329 & 0.771 & 1096 \\
\hline 16 & 859 & 5.4 & 25.2 & 29.7 & 0.697 & 1232 & 14.7 & 0.659 & 1304 & 0.801 & 1073 & 0.810 & 1060 \\
\hline 17 & 975 & 5.8 & 25.2 & 31.8 & 0.746 & 1308 & 15.2 & 0.703 & 1387 & 0.885 & 1102 & 0.884 & 1102 \\
\hline 18 & 997 & 6.0 & 25.9 & 31.8 & 0.734 & 1359 & 15.4 & 0.693 & 1439 & 0.859 & 1161 & 0.858 & 1162 \\
\hline 19 & 998 & 6.0 & 24.0 & 30.0 & 0.746 & 1339 & 14.4 & 0.704 & 1418 & 0.850 & 1174 & 0.849 & 1175 \\
\hline 20 & 862 & 4.6 & 19.8 & 31.0 & 0.742 & 1162 & 13.3 & 0.682 & 1263 & 0.848 & 1016 & 0.840 & 1026 \\
\hline Mean & 597 & 3.9 & 33.9 & 30.4 & 0.520 & 1114 & 17.2 & 0.487 & 1190 & 0.586 & 990 & 0.589 & 986 \\
\hline
\end{tabular}




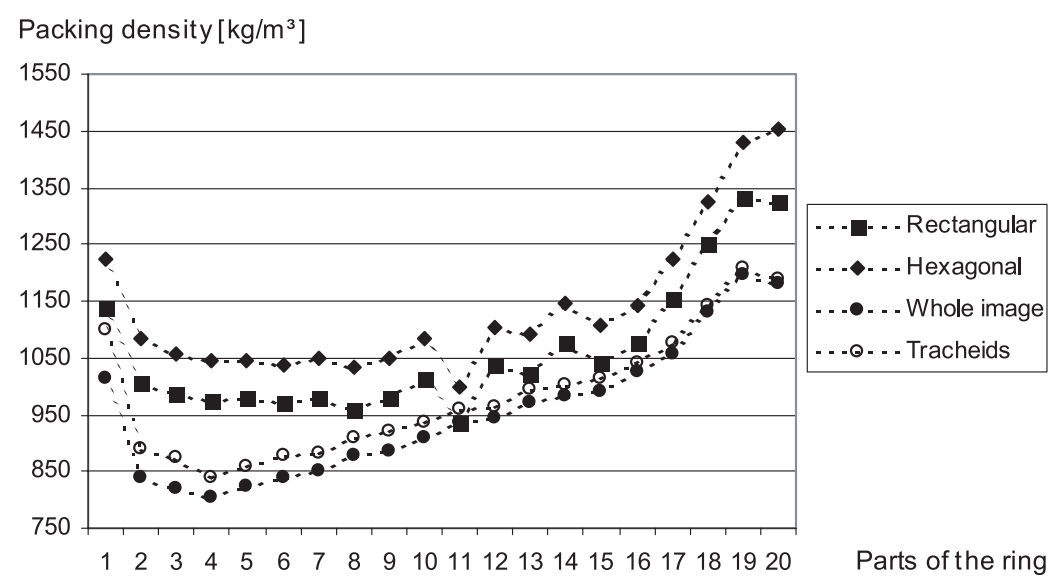

Figure 6. France spruce ring: Packing density $\left(\mathrm{kg} / \mathrm{m}^{3}\right)$ calculated from the rectangular and hexagonal models and measured with image analysis (analysis of the whole image and tracheids only).

\subsection{Planimetry compared to image analysis}

Fukazawa [13] measured a cell wall proportion in area increasing from $\pm 35 \%$ at the beginning to $\pm 90 \%(80 \%$ for the juvenile wood) at the end of the ring and for Quirk [31] it varied from 30 to $90 \%$. Our planimetry and image analysis yield a somewhat lower cell wall proportion, but in the same range of variation.

The cell wall proportion obtained by the different methods (Tabs. III to VIII) rises from, in order, planimetry with the hexagonal model, planimetry with the rectangular model, image analysis on masked image to image analysis on whole ring image. This is illustrated on the Figures 5 and 6. As planimetry uses a cell shape model, the calculated proportion is that of the tracheid walls only and this proportion will thus logically be inferior than those measured with image analysis. When rays and canal walls are excluded the measured proportion gets closer to the planimetric results.

The methods themselves are also responsible for some of those differences. The use of a rectangular or hexagonal model for the tracheid shape leads to simplifications. Those models assume that the cell wall thickness is constant all around the perimeter of the cells. The hexagonal one also supposes the equality of the radial and tangential dimensions of the tracheids.

\section{DISCUSSION}

\subsection{Apparent density of the cell wall}

After Stamm's 1929 works, inferior cell wall and wood substance densities were obtained by physical measurements (helium, mercury, benzene and toluene displacements). A mean value of $1460 \mathrm{~kg} / \mathrm{m}^{3}$ which may be considered as the dry cell wall density value, and also as the density of the dry wood substance (as the dry cell wall would be essentially non porous $[34,35,39,40,42,44])$ may be brought out for conifers [4, 19, $38,39,43-45]$.
Planimetry and image analysis both give apparent cell wall density values of around $1000-1400 \mathrm{~kg} / \mathrm{m}^{3}$, values different from $1530 \mathrm{~kg} / \mathrm{m}^{3}$ and $1460 \mathrm{~kg} / \mathrm{m}^{3}$.

The literature points out that all the optical estimations of the apparent density of the cell wall [19, 30, 32, 33, 41, 43, 47] show a clear tendency for being far weaker than the value of $1460 \mathrm{~kg} /$ $\mathrm{m}^{3}$. Only Quirk [29] obtains values closer to $1460 \mathrm{~kg} / \mathrm{m}^{3}$.

To our knowledge there is not only one unique explanation of this difference between the value of 1000 and $1460 \mathrm{~kg} / \mathrm{m}^{3}$ but some suppositions can be made.

- The quality of the observed sample is of great importance. The measurements using automated microscopy on wood sections are at least as accurate as any other practical quantification method but there is a requirement that the samples be free from damage, thin and uniformly stained. Danborg [5] working with image analysis mentions that the quality of the image depends on the quality of the microtome section, and the quality and resolution of the microscope and camera. Indeed, intercellular spaces are only detected if the system's resolution allows it.

- Some corrections should be applied in view of the measurements conditions.

- The thickness of the section may be responsible for a parallax problem leading to an overestimation of the cell wall area $[1,5,25]$. A correct focus during the acquisition of the images is thus essential. For Donaldson [6], there can be an effect of "out-of-focus" due to the thickness of the sections and ray cells and pits may be filled by the inclusion of lateral walls on the deepness of the image.

- The treatment of the wood sample leading to the measured support (section) may not leave the wood intact. Fengel [11] reports in this way that fibres are getting thicker during wood impregnation as the polymerisation reaction occurs in a media that penetrates into the fibre quicker than in the outside media. Wood slicing may also be responsible of an increase of the cell wall area [19].

- During drying, sections are subjected to shrinkage and this latest would be responsible of a reduction $[6,7,30]$ or of an increase [19] of the cell wall proportion. 
- The moisture content of a mounted section is not known with accuracy and according to Boutelje [2] the observed shrinkage varies with the used drying technique.

- Even if rays and canals are excluded, the measured area proportion is that of the visible material on a transverse plane that is the cell wall but also the middle lamellae, the cell wall thickenings in contact of the rays. All the pre-existing but also the eventual neo-formed voids, that aren't detected, are also considered as part of the matter. Those voids may play a great role in the difference between the optically assessed packing density of around $1000 \mathrm{~kg} / \mathrm{m}^{3}$ and the cell wall density measured directly on wood substance of around $1460 \mathrm{~kg} / \mathrm{m}^{3}$.

\subsection{Interpretation of the intra ring wood density variations}

From EW to LW, the wood density increase is the consequence of (i) anatomical modifications: increase of the cell wall width and increase of the number of cell rows in both directions (but more slightly in the tangential direction) and (ii) chemical ones: the cell wall density increases slightly from EW to LW as a consequence of the variation of the structure and chemical composition of the cell wall.

The anatomical changes are mainly responsible for the wood density variations as the packing density variations play only a minor role.

\subsubsection{Anatomical point of view: cells sizes measured by planimetry}

From EW to LW the tracheids become smaller and their walls thicker. These anatomical variations result in an increase of the cell wall proportion all along the ring. The changes of the cells sizes are greater in the radial $[9,17]$ than in the tangential direction [8] as the number of cells rows increases much more in the radial than in the tangential direction.

The more important variation of the cell wall thickness compared to those of the cells size as already observed $[12,15]$ confirms that the cell wall thickness variations play a major role in the wood density variations.

\subsubsection{Chemical point of view: evolution of the apparent density of the cell wall}

The calculated apparent density of the cell wall (with both methods) shows a slight increase from EW to LW that may be explained by anatomical and chemical considerations.

In the $\mathrm{LW}$ the cell walls thickness of the $S_{2}$ (the richest in cellulose) and $S_{1}$ layers, are strongly and weakly thicker than in the $\mathrm{EW}$, respectively while the $\mathrm{S}_{3}$ layer and the primary wall have almost the same thickness all along the ring [10].

Stamm [37] notices that the compound middle lamella (primary wall and middle lamella together) is much thicker in the LW than in the EW as for Fukazawa [13], the middle lamella proportion in relation to the entire cell wall is of $10-15 \%$ and stays practically constant all along the ring. As LW fibres are more circular, more middle lamella is found at the junction of four fibres [37]. The taking into account of the middle lamella in the area measurements would thus play a more important role in the LW.

From a chemical point of view, the composition of the cell wall also varies, explaining a superior cell wall density in LW than in EW. Yiannos [47] finds LW cell wall densities superior by at least $100 \mathrm{~kg} / \mathrm{m}^{3}$ than in EW. Wilfong's [45] observations also point in that direction and his explanation is that the thicker $\mathrm{S}_{2}$ layer and the higher cellulose content of the $\mathrm{LW}$ cell wall account for the difference observed. Stamm [37] confirms the increase of the cellulose content of the cell wall from EW to LW and observes an increase of the cell wall density from EW $\left(1416 \mathrm{~kg} / \mathrm{m}^{3}\right)$ to $\mathrm{LW}\left(1450 \mathrm{~kg} / \mathrm{m}^{3}\right)$ for the rings close to the pith, but this increase becomes negligible for rings 26 to 33 on average: cell wall density $=1459$ for the $E W$ and $1461 \mathrm{~kg} / \mathrm{m}^{3}$ for the LW.

\section{CONCLUSIONS}

We have verified that the knowledge of the (i) tracheid geometry and (ii) the usually admitted value of the cell wall density allow us to calculate intra ring wood density profiles which are similar in terms of variations than the $\mathrm{X}$-rays wood density profiles but very different in average. Thus it appears at least necessary to calibrate carefully the optical measurement by using an apparent cell wall density which is far weaker from the effective cell wall density of $1460 \mathrm{~kg} / \mathrm{m}^{3}$ obtained by physical measurements. In addition this calibration needs to vary inside the ring in order to match perfectly both profiles according to the method used for the determination of the cell wall proportion (Fig. 6). The effects of the treatments of the wood sample (embedding, slicing, drying...) and of the image of the rings (acquisition procedure, thresholding...) should be carefully tested and accurately quantified.

Based on this result gained for raw material from three important softwood species, a further and useful development could be to test how and if it is possible to determine, for a given and known species, the tracheid geometry variations directly from the intra ring density profile.

Acknowledgements: We would like to thank Simone Garros who prepared all the sections of this study. Funding for this work was provided by a Belgian F.N.R.S. PhD research grant to Valérie Decoux and by a French grant from the "Région Lorraine".

\section{REFERENCES}

[1] Berlyn G.P., A Hypothesis for Cell Wall Density, For. Prod. J. 18 (1968) 34-36.

[2] Boutelje J., On shrinkage and change in microscopic void volume during drying, as calculated from measurements on microtome cross sections of Swedish Pine (Pinus sylvestris L.), Svensk Papperstidning 65 (1962) 209-215.

[3] Brown H.P., Panshin A.J., Forsaith C.C., Textbook of wood technology, Vol. 1, McGraw-Hill Book Co., Inc., New York, NY, 1949.

[4] Christensen G.N., Hergt H.F.A., The Apparent Density of Wood in Non-Swelling Liquids, Holzforschung 22 (1968) 165-170.

[5] Danborg F., Pedini M., The use of X-ray densitometry and digital image analysing for wood technological research, Internal of the 
Royal Veterinary and Agricultural University, Department of Economics and Natural Resources, KVL, Hrsholm, Denmark, 1990.

[6] Donaldson L.A., Lausberg M.J.F., Comparison of conventional transmitted light and confocal microscopy for measuring wood cell dimensions by image analysis, IAWA J. 19 (1998) 321-336.

[7] Ellwood E.L., Wilcox W.W., The Shrinkage of Cell Walls and Cell Cavities in Wood Microsections, For. Prod. J. 12 (1962) 235-242.

[8] Erickson H.D., Harrison A.T., Douglas - Fir Wood Quality Studies, Part I: Effects of Age and Stimulated Growth on Wood Density and Anatomy, Wood Sci. Technol. 8 (1974) 207-226.

[9] Fengel D., Stoll M., On the Variation of the Cell Cross Area, the Thickness of the Cell Wall and of the Wall Layers of Sprucewood Tracheids within an Annual Ring, Holzforschung 27 (1973) 1-7.

[10] Fengel D., The Ultrastructure of Cellulose from Wood, Part I: Wood as the Basic Material for the Isolation of Cellulose, Wood Sci. Technol. 3 (1969) 203-217.

[11] Fengel D., Ultramicrotomy, Its Application in Wood Research, Wood Sci. Technol. 1 (1967) 191-204.

[12] Ferrand J.C., Réflexions sur la densité du bois, $1^{\mathrm{e}}$ Partie: Définition de la densité du Bois, Holzforschung 36 (1982) 99-105.

[13] Fukazawa K., Imagawa H., Quantitative Analysis of Lignin Using an UV Microscopic Image Analyser. Variation Within One Growth Increment, Wood Sci. Technol. 15 (1981) 45-55.

[14] Hannrup B., Danell O., Ekberg I., Moëll M., Relationships between wood density and tracheid dimensions in Pinus sylvestris L., Wood Fiber Sci. 33 (2001) 173-181.

[15] Heger L., Parker M.L., Kennedy R.W., X-Ray Densitometry: A Technique and An Example of Application, Wood Sci. 7 (1974) 140-148.

[16] Ifju G., Within-Growth-Ring Variation in Some Physical Properties of Southern Pine Wood, Wood Sci. 2 (1969) 11-19.

[17] Ivkovich M., Koshy M.P., Wood Density Measurement: Comparison of X-ray, Photometric, and Morphometric Methods, Timber Management Toward Wood Quality and End-Product Value, CTIA/IUFRO International Wood Quality Workshop, 1997.

[18] Jayme G., Krause T., Uber die Packungsdichte der Zellwände in Laubhölzern, Holz Roh- Werkst. 21 (1963) 14-19.

[19] Kellogg R.M., Wangaard F.F., Variation in the cell-wall density of wood, Wood Fiber 1 (1969) 180-204.

[20] Koubaa A., Zhang S.Y.T., Makni S., Defining the transition from earlywood to latewood in black spruce based on intra-ring wood density profiles from X-ray densitometry, Ann. For. Sci. 59 (2002) 519-524.

[21] Lindström H., Fiber length, tracheid diameter, and latewood percentage in Norway spruce: Development from pith outwards, Wood Fiber Sci. 29 (1997) 21-34.

[22] Mörling T., Evaluation of annual ring width and ring density development following fertilisation and thinning of Scots pine, Ann. For. Sci. 59 (2002) 29-40.

[23] Mothe F., Duchanois G., Leban J.M., Owoundi R.E., Perrin J.R., Qualification des bois par microdensitométrie, Contrat Région Lorraine - INRA, Décision DBCR 158-90 (Code INRA 3086A), 1990.

[24] Mothe F., Duchanois G., Zannier B., Leban J.-M., Analyse microdensitométrique appliquée au bois: méthode de traitement des données utilisée à l'Inra-ERQB (programme Cerd), Ann. Sci. For. 55 (1998) 301-313.

[25] Park W-K., Telewski F.W., Measuring maximum latewood density by image analysis at the cellular level, Wood Fiber Sci. 25 (1993) 326-332.
[26] Polge H., Fifteen Years of Wood Radiation Densitometry, Wood Sci. Technol. 12 (1978) 187-196.

[27] Polge H., Établissement des courbes de variation de la densité du bois par exploration densitométrique de radiographies d'échantillons prélevés à la tarière sur des arbres vivants - Applications dans les domaines technologique et physiologique, Ann. Sci. For. 23 (1966) 1-215.

[28] Polge H., Le bois juvénile des conifères, Rev. For. Fr. 86 (1964) 473-505.

[29] Quirk J.T., Cell Wall Density of Douglas Fir by two Optometric Methods, Wood Fiber Sci. 16 (1984) 224-236.

[30] Quirk J.T., Shrinkage and related properties of Douglas-fir cell walls, Wood Fiber Sci. 16 (1984) 115-133.

[31] Quirk J.T., Dot-grid integrating eyepiece: two sampling techniques for estimating cell wall areas, Wood Sci. 8 (1975) 88-91.

[32] Quirk J.T., Smith D., Comparison of dual linear and dot-grid eyepiece methods for estimating wood properties of Douglas-fir, Wood Sci. 8 (1975) 92-96.

[33] Smith D.M., Rapid Measurement of Tracheid Cross-Sectional Dimensions of Conifers: Its Application to Specific Gravity Determinations, For. Prod. J. 15 (1965) 325-334.

[34] Stamm A.J., History of Two Phases of Wood Physics, Wood Sci. Technol. 1 (1967) 186-190.

[35] Stamm A.J., Wood and Cellulose Science, North Carolina State of the University of North Carolina at Raleigh, 1964.

[36] Stamm A.J., Density of wood substance, absorption by wood, and permeability of wood, J. Phys. Chem. 33 (1929) 398-414.

[37] Stamm A.J., Sanders H.T., Specific Gravity of the Wood Substance of Loblolly Pine as Affected by Chemical Composition, Tappi 49 (1966) 397-400.

[38] Stayton C.L., Hart C.A., Determining Pore-Size Distribution in Softwoods with a Mercury Porosimeter, For. Prod. J. 15 (1965) 435-440.

[39] Stone J.E., Scallan A.M., Aberson G.M.A., The Wall Density of Native Cellulose Fibres, Pulp and Paper Research Institute of Canada 67 (1966) T263-T268.

[40] Stone J.E., Scallan A.M., A Study of Cell Wall Structure by Nitrogen Adsorption, Pulp and Paper Research Institute of Canada 66 (1965) T407-T414.

[41] Tsoumis G., Microscopic Measurement of the Amount of Cell Wall Substance in Wood and Its Relationship to Specific Gravity, Tappi 47 (1964) 675-677.

[42] Tsoumis G., Passialis C., Effect of growth rate and abnormal growth on wood substance and cell-wall density, Wood Sci. Technol.11 (1977) 33-38.

[43] Wangaard F.F., Cell-Wall Density of Wood With Particular Reference to the Southern Pines, Wood Sci. 1 (1969) 222-226.

[44] Weatherwax R.C., Tarkow H., Cell Wall Density of Dry Wood, For. Prod. J. 18 (1968) 83-85.

[45] Wilfong J.G., Specific Gravity of Wood Substance, For. Prod. J. 16 (1966) 55-61.

[46] Wimmer, R., Intra-annual cellular characteristics and their implications for modeling softwood density. Wood Fiber Sci. 27 (1995) 413-420.

[47] Yiannos P.N., The apparent Cell-Wall Density of Wood and Pulp Fibers, Tappi 47 (1964) 468-471. 